\title{
Recent progress in CO oxidation over Pt-group-metal catalysts at low temperatures
}

\author{
Jian Lin, Xiaodong Wang\#, Tao Zhang* \\ State Key Laboratory of Catalysis, Dalian Institute of Chemical Physics, Chinese Academy of Sciences, Dalian, 116023, Liaoning, China
}

\section{A R T I C L E I N F O}

\section{Article history:}

Received 25 June 2016

Accepted 30 July 2016

Published 5 November 2016

\section{Keywords:}

Carbon monoxide oxidation

Gold

Platinum group metal

Low temperature

Size effect

Interface

\begin{abstract}
A B S T R A C T
CO oxidation is probably the most studied reaction in heterogeneous catalysis. This reaction has become a hot topic with the discovery of nanogold catalysts, which are active at low temperatures (at or below room temperature). Au catalysts are the benchmark for judging the activities of other metals in $\mathrm{CO}$ oxidation. Pt-group metals (PGMs) that give comparable performances are of particular interest. In this mini-review, we summarize the advances in various PGM (Pt, Pd, Ir, Rh, Ru) catalysts that have high catalytic activities in low-temperature $\mathrm{CO}$ oxidation arising from reducible supports or the presence of $\mathrm{OH}$ species. The effects of the size of the metal species and the importance of the interface between the metal and the reducible support are covered and discussed in terms of their promotional role in $\mathrm{CO}$ oxidation at low temperatures.
\end{abstract}

(C) 2016, Dalian Institute of Chemical Physics, Chinese Academy of Sciences. Published by Elsevier B.V. All rights reserved.

alyst has low thermal stability at room temperature, undesirable behavior under transient cycling conditions, and is easily deactivated in the presence of sulfur and moisture [6,7].

In 1987, Haruta et al. [8,9] reported that an oxide-supported $\mathrm{Au}$ catalyst prepared using a wet chemistry method gave an unexpectedly high performance in $\mathrm{CO}$ oxidation at low temperatures. The nanoscale Au catalyst was highly dispersed, with good water resistance and stability. Au catalysts became the benchmark system for low-temperature CO oxidation. Interest in the CO oxidation reaction increased during the "gold rush" and as well as being used as from a model reaction to a chemical probe for studying the surface properties of catalysts $[1,10,11]$. Pt-group-metal (PGMs; Pt, Pd, Ir, Rh, Ru) catalysts have been studied for almost a century since Langmuir's work [12]; however, they are generally one order of magnitude less

\footnotetext{
* Corresponding author. Tel: +86-411-84379015; Fax: +86-411-84691570; E-mail: taozhang@dicp.ac.cn

\# Corresponding author. Tel: +86-411-84379680; Fax: +86-411-84691570; E-mail: xdwang@dicp.ac.cn

This work was supported by the National Natural Science Foundation of China (21076211, 21203181, 21576251, 21676269), the "Strategic Priority Research Program" of the Chinese Academy of Sciences (XDB17020100), the National Key projects for Fundamental Research and Development of China (2016YFA0202801) and Department of Science and Technology of Liaoning Province under contract of 2015020086-101.

DOI: 10.1016/S1872-2067(16)62513-5 | http://www.sciencedirect.com/science/journal/18722067 | Chin. J. Catal., Vol. 37, No. 11, November 2016
} 


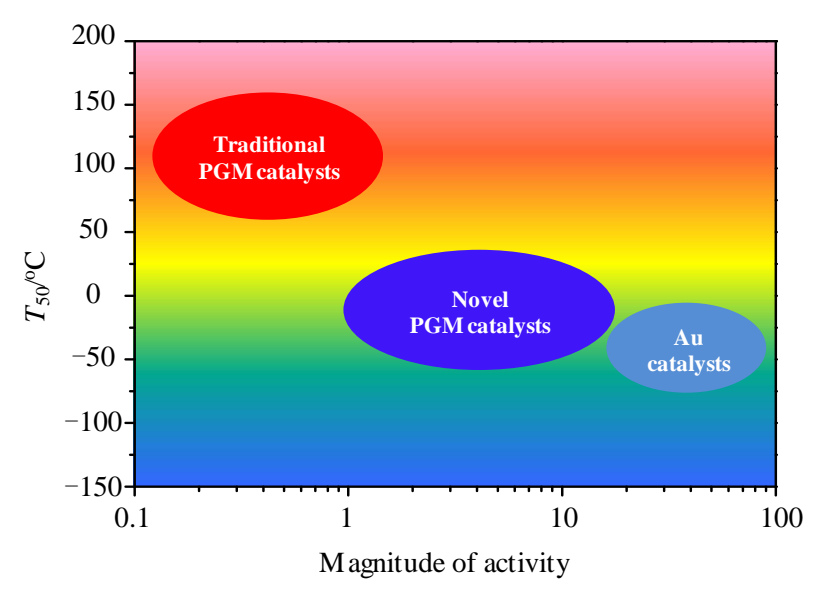

Fig. 1. Conceptual description of performances of $\mathrm{Au}$ and Pt-group-metal catalysts for CO oxidation in terms of the temperature for $50 \%$ CO conversion and the magnitude of specific activities.

active than Au catalysts in low-temperature CO oxidation, as shown in Fig. 1. Although much effort has been made to improve their activities in $\mathrm{CO}$ oxidation, e.g., by adding promoters or using reducible oxides as supports, the use of PGM catalysts for room-temperature or cryogenic CO oxidation remains a challenge.

In $\mathrm{CO}$ oxidation over metal-based catalysts, $\mathrm{O}_{2}$ adsorption and activation is often regarded as the rate-limiting step [13]. The use of traditional PGM catalysts with inert supports such as $\mathrm{SiO}_{2}, \mathrm{Al}_{2} \mathrm{O}_{3}$, and zeolites is inefficient. On this type of catalyst, there is serious competition between adsorption and activation of $\mathrm{CO}$ and $\mathrm{O}_{2}$ on the metal sites; $\mathrm{CO}$ is strongly adsorbed, which seriously hinders $\mathrm{O}_{2}$ adsorption and activation. A high working temperature $\left(>100{ }^{\circ} \mathrm{C}\right)$ is therefore needed to weaken $\mathrm{CO}$ adsorption and facilitate adsorption of $\mathrm{O}_{2}[14,15]$. Effective strategies for weakening the adsorption of CO on PGMs at low temperatures and promoting adsorption and activation of $\mathrm{O}_{2}$ are therefore needed. Various strategies for improving room-temperature and cryogenic catalytic activities in $\mathrm{CO}$ oxidation, such as reducing the PGM particle size from nano to sub-nano or to single atoms, and engineering metal-metal oxide (hydroxide) interfaces, have been used to develop new PGM catalysts (Fig. 1) with adsorption sites on the metal and the support and activation of oxygen in atomic or molecular form.

\section{Advanced catalysts for low-temperature CO oxidation}

In the past decade, it has been reported that $\mathrm{CO}$ conversion at or below room temperature can reach $100 \%$ over novel promoted PGM catalysts for CO oxidation or CO preferential oxidation (PROX) in an $\mathrm{H}_{2}$-rich stream. In the following sections, we summarize these advances, concentrating on the role of reducible oxide and $\mathrm{OH}$ species.

\subsection{Reducible promoter or support}

Reducible oxides as supports or promoters can supply the sites for $\mathrm{O}_{2}$ adsorption, significantly improving the low-temperature activities of PGM catalysts for CO oxidation. Iron oxide has been the most intensively studied metal oxide because of its outstanding promotional effect.

Deng's group focused on improving the CO oxidation performances below room temperature on Pd and Pt metals with $\mathrm{FeO}_{x}$ as a support. They prepared the first $\mathrm{FeO}_{x}$-supported $\mathrm{Pd}$ catalyst with high activity and achieved complete oxidation of $\mathrm{CO}$ at $-15{ }^{\circ} \mathrm{C}$ [16]. It was suggested that the partly reduced $\mathrm{FeO}_{x}$ support participated in $\mathrm{CO}$ oxidation, acting as an oxygen supply for reactions with $\mathrm{CO}$ on $\mathrm{Pt}$ and $\mathrm{Pd}$ with low-activation energy (30-34 kJ/mol). The presence of an oxygen reservoir on the $\mathrm{FeO}_{x}$ support has opened up new routes in the search for high activity in low-temperature CO oxidation $[17,18]$.

$\mathrm{FeO}_{x}$ promoters can also improve the low-temperature activity in CO oxidation over inert oxide supported PGM catalysts. Shen's group prepared colloidal Pt-Fe bimetallic nanoparticles using a modified polylol method [19]. The prepared nanoparticles were deposited on an $\mathrm{Al}_{2} \mathrm{O}_{3}$ support. The $\mathrm{PtFe}_{3} / \mathrm{Al}_{2} \mathrm{O}_{3}$ catalyst gave a CO conversion of $99 \%$ at $30{ }^{\circ} \mathrm{C}$. Zhang et al. [20] designed a bifunctional catalyst, $\mathrm{IrFe} / \mathrm{Al}_{2} \mathrm{O}_{3}$, for the reaction between $\mathrm{CO}$ adsorbed on $\mathrm{Ir}$ sites and $\mathrm{O}_{2}$ adsorbed on $\mathrm{FeO}_{x}$. A ${ }^{57} \mathrm{Fe}$ Mössbauer spectroscopic study suggested that the PROX activity increased with increasing amount of $\mathrm{Fe}^{2+}$ sites, and that $\mathrm{Fe}^{2+}$ species were the sites for oxygen adsorption [21]. Freund et al. [22] proposed that $\mathrm{O}$ adsorbed on $\mathrm{FeO}$ produced oxygen-rich $\mathrm{FeO}_{x}(1<x<2)$ species, which could react with $\mathrm{CO}$ over $\mathrm{FeO} / \mathrm{Pt}$ catalysts. Bao's group suggested that interface-confined coordinatively unsaturated ferrous sites neighboring Pt acted as active centers for $\mathrm{O}_{2}$ adsorption and activation. This enabled total CO oxidation at room temperature, as shown in Fig. 2 [23]. All these studies show that low-valence Fe sites are critical for low-temperature $\mathrm{CO}$ oxidation.

$\mathrm{Fe}(\mathrm{OH})_{x}$, in which the $\mathrm{Fe}-\mathrm{O}$ bond length is longer than that in traditional $\mathrm{Fe}_{2} \mathrm{O}_{3}$, is easily reduced to form $\mathrm{Fe}^{2+}$ sites [24]. Zhang el al. [25-29] designed a series of PGM catalysts of Ir, Rh, $\mathrm{Pd}, \mathrm{Pt}$ based on this property of $\mathrm{Fe}(\mathrm{OH})_{x}$. It was found that $\mathrm{Fe}(\mathrm{OH})_{x}$ generally promoted high dispersion of these metal species at the sub-nanoscale, i.e., around $1 \mathrm{~nm}$, and gave complete CO conversion at room temperature. This versatile design strategy was based on the $\mathrm{Fe}(\mathrm{OH})_{x}$ support promoting the adsorption and activation of $\mathrm{O}_{2}$, making the adsorbed oxygen species react with adsorbed $\mathrm{CO}$ at the metal-support interface through a noncompetitive Langmuir-Hinshelwood mechanism.

When the Pt loading was decreased to $0.17 \mathrm{wt} \%$, all the Pt species were dispersed as single atoms, without the presence of any clusters or particles [30]. CO oxidation and CO preferential oxidation tests showed that the single-atom catalyst was two to three times more active than the cluster catalyst. However, because of the current limitations of low Pt loading of single-atom catalysts, total conversion of $\mathrm{CO}$ can only be achieved at a PEMFC working temperature of $80^{\circ} \mathrm{C}$. It is therefore still a challenge to achieve good performances with such low-loaded single-atom catalysts in certain catalytic reactions or to prepare high-loaded single-atom catalysts that improve the overall performance [31-33].

In addition to iron oxide, other reducible oxides are also effective for PGM-catalyzed CO oxidation. Zhu et al. [34] prepared 

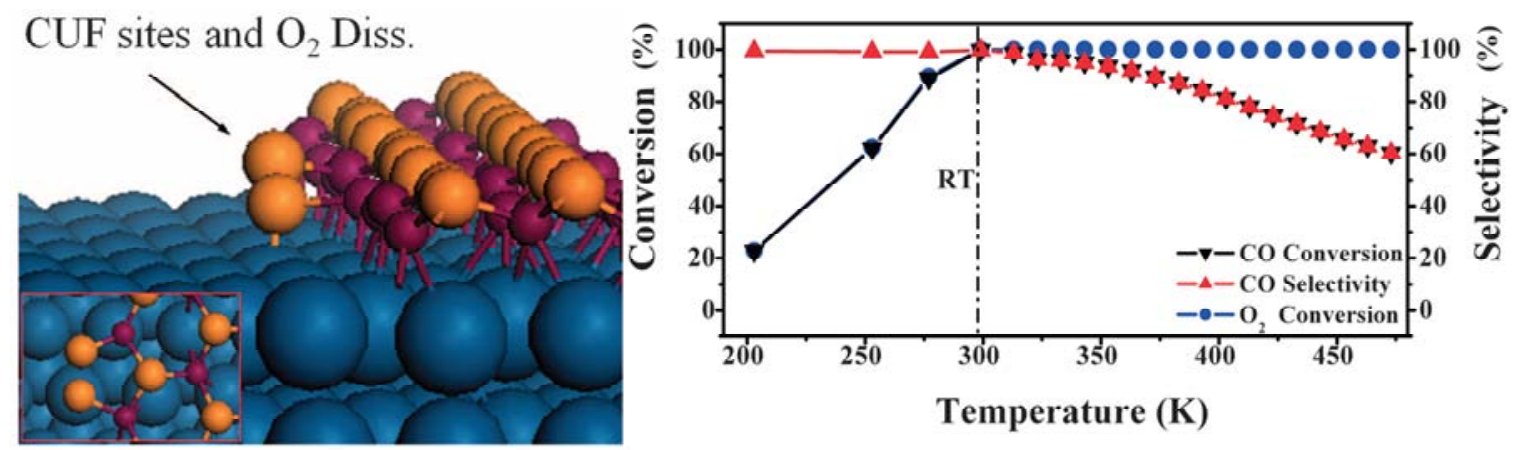

Fig. 2. Left: $\mathrm{O}_{2}$ dissociative adsorption on coordinatively unsaturated ferrous (CUF) sites. Pt, Fe, and $\mathrm{O}$ atoms are indicated by blue, purple, and brown balls, respectively; Right: PROX reaction over $\mathrm{Pt}-\mathrm{Fe} / \mathrm{SiO}_{2}$ catalysts under the conditions $1 \% \mathrm{CO}, 0.5 \% \mathrm{O}_{2}$, and $98.5 \% \mathrm{H}_{2}$. Space velocity is 36000 $\mathrm{mL} / \mathrm{g} \cdot \mathrm{h}$ reprinted from Ref. [23].

a $\mathrm{Pd} / \mathrm{CeO}_{2}-\mathrm{TiO}_{2}$ catalyst using an incipient wet impregnation method; it gave complete $\mathrm{CO}$ conversion at room temperature despite significant deactivation after running for $100 \mathrm{~min}$. It was suggested that the high activity of $\mathrm{Pd} / \mathrm{CeO}_{2}-\mathrm{TiO}_{2}$ was the result of enhancement of $\mathrm{CO}$ activation by facilitation of the reduction of $\mathrm{Pd}^{2+}$ to $\mathrm{Pd} 0$, and $\mathrm{O}_{2}$ activation through improvement of the surface oxygen supply and oxygen vacancy formation. $\mathrm{CoO}_{x}$ acts as a promoter in yttria-stabilized zirconia (YSZ)-supported Pt catalysts. This catalyst with $1 \mathrm{wt} \% \mathrm{Pt}$ and $\mathrm{Pt} / \mathrm{Co}=10$ gave around $100 \%$ CO conversion and reduced the CO concentration to below $10 \mathrm{ppm}$ at $60{ }^{\circ} \mathrm{C}$ [35]. Similarly, a $\mathrm{Ru} @ \mathrm{Pt}$ core-shell catalyst significantly increased CO conversion compared with that achieved using the monometal catalyst; it gave $100 \% \mathrm{CO}$ conversion at $20{ }^{\circ} \mathrm{C}\left(0.1 \% \mathrm{CO}\right.$ and $0.5 \% \mathrm{O}_{2}$ in $\left.\mathrm{H}_{2}\right)$ [36]. All these catalysts can work at room temperature or give good performances in the presence of $\mathrm{H}_{2}$.

$\mathrm{TiO}_{2}$ is a popular support on which oxygen atoms or molecular oxygen can participate in low-temperature oxidation of $\mathrm{CO}$ $[13,37]$. Okumura et al. [38] prepared a $\mathrm{TiO}_{2}$-supported Ir catalyst using a deposition-precipitation method. The Ir species were present as a highly dispersed, $2 \mathrm{~nm}$ thick, positively charged layer. This catalyst gave $100 \%$ CO conversion at room temperature with $1 \%$ CO in air at a space velocity of $20000 \mathrm{~mL}$ $\mathrm{g}_{\mathrm{cat}^{-1}} \mathrm{~h}^{-1}$. Yang et al. [39] found that a special wire-like $\mathrm{RuO}_{2}$ on $\mathrm{TiO}_{2}$ catalyst favored dissociative adsorption of $\mathrm{O}_{2}$ and easy release of adsorbed oxygen, giving it a comparable activity to that of $\mathrm{Au} / \mathrm{TiO}_{2}$. Recently, Yates and co-workers [40] proposed a new reaction mechanism for $\mathrm{CO}$ oxidation on $\mathrm{Au} / \mathrm{TiO}_{2}$ in which the weakly adsorbed $\mathrm{CO}$ on $\mathrm{TiO}_{2}$ sites diffused to react with $\mathrm{O}_{2}$ activated at the interface between $\mathrm{Au}$ and $\mathrm{TiO}_{2}$; $\mathrm{CO}$ oxidation at cryogenic temperatures was achieved (Fig. 3). The sequential delivery and reaction of $\mathrm{CO}$ first at $\mathrm{TiO}_{2}$ sites and then at Au sites indicate that the catalytic reaction occurs at the $\mathrm{Au}$ nanoparticle perimeters. The role of $\mathrm{TiO}_{2}$ in the adsorption and activation of $\mathrm{CO}$ shows that the reaction mechanism using this new catalyst differs from that at room temperature. The titanate sites, which have neighboring metal nanoparticles, appear to be responsible for opening up this new reaction channel [41]. The feasibility of such a mechanism for PGM-catalyzed CO oxidation at cryogenic temperatures has recently been verified. Guan et al. [42] prepared a novel $\mathrm{Rh} / \mathrm{TiO}_{2}$ catalyst with highly dispersed sub-nano $\mathrm{Rh}$ species
(0.4-0.8 nm). Fig. 4 shows that $\mathrm{O}_{2}$ was easily activated as $\mathrm{Rh}-\mathrm{O}-\mathrm{O}-\mathrm{Ti}$ (molecular superoxide species) at the $\mathrm{Rh}-\mathrm{Ti}$ perimeter sites when $\mathrm{Rh}$ was present as sub-nano species. The superoxide reacted with the weakly adsorbed $\mathrm{CO}$ on $\mathrm{TiO}_{2}$ sites, resulting in high activity at cryogenic temperatures, with total CO conversion at $-50{ }^{\circ} \mathrm{C}$. This confirms that the performances of PGM catalysts can rival that of the standard Au catalyst in the oxidation of $\mathrm{CO}$ far below room temperature.

\subsection{Promotional role of $\mathrm{OH}$ species}

The $\mathrm{OH}$ species that come from humidity or are generated as intermediates from $\mathrm{H}_{2}$ reduction or during the PROX process are unavoidable in low-temperature CO oxidation in practical applications [43]. Usually, a moderate amount of $\mathrm{OH}$ species can promote low-temperature $\mathrm{CO}$ oxidation over $\mathrm{Au}$ catalysts. Daté et al. [44] suggested that water facilitated the activation of oxygen or decomposition of carbonates on Au catalysts. Saavedra et al. [45] recently provided direct evidence of a water-mediated reaction mechanism for room-temperature $\mathrm{CO}$ oxidation over an $\mathrm{Au} / \mathrm{TiO}_{2}$ catalyst. They found that the cover-

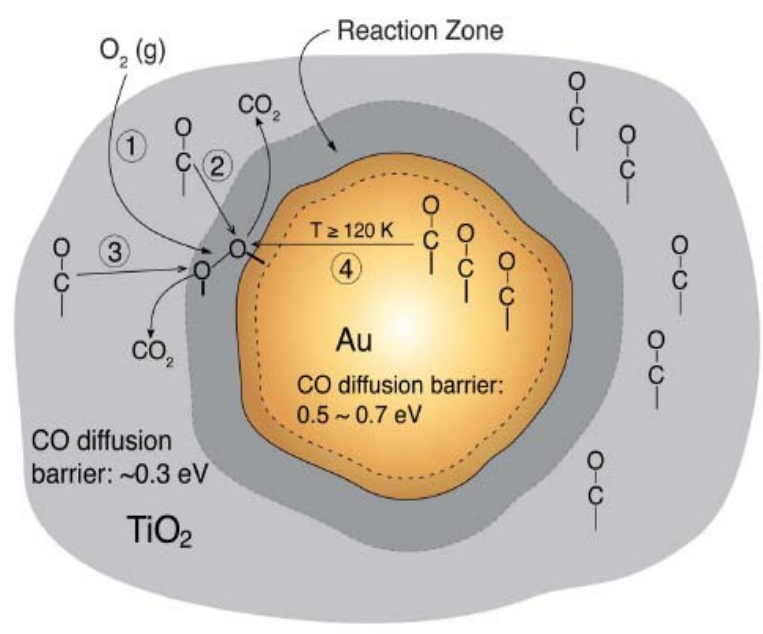

Fig. 3. Schematic of $\mathrm{CO}$ oxidation mechanism on $\mathrm{Au} / \mathrm{TiO}_{2}$, which showed that the $\mathrm{CO}$ adsorbed on $\mathrm{TiO}_{2}$ sites, rather than that on $\mathrm{Au}$ sites, facilely reacted with the $\mathrm{O}_{2}$ activated at the interface between $\mathrm{Au}$ and $\mathrm{TiO}_{2}$ at cryogenic temperature reprinted from Ref. [40]. 


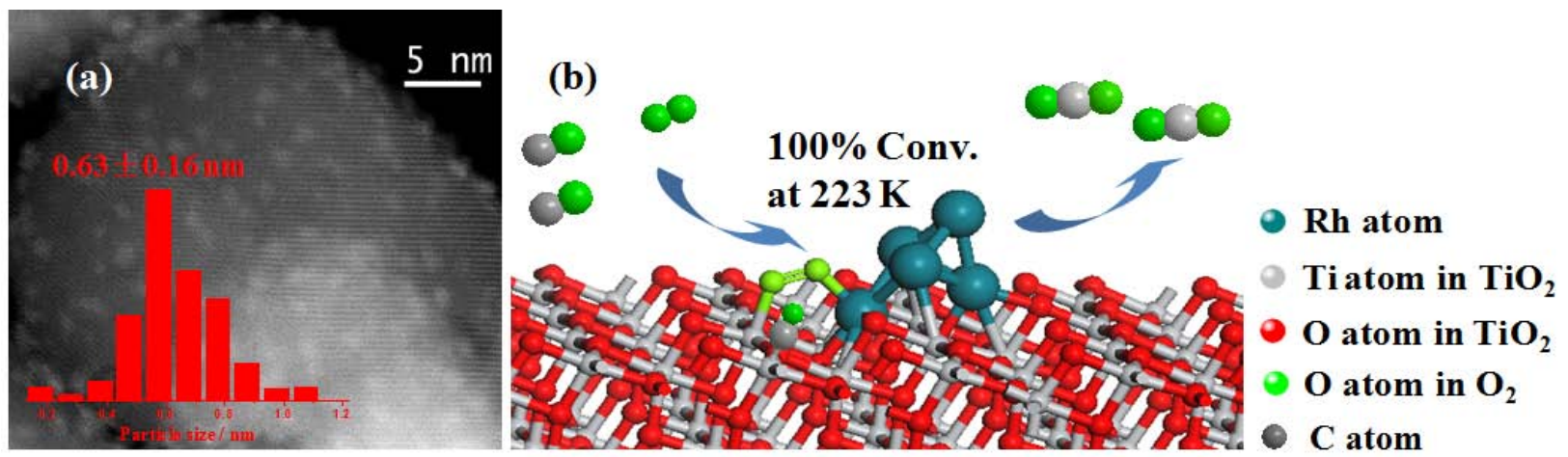

Fig. 4. (a) typical HAADF-STEM image and size distribution of $\mathrm{Rh} / \mathrm{TiO}_{2}$ catalyst; (b) reaction model of $\mathrm{CO}$ adsorbed on $\mathrm{TiO}_{2}$ with $\mathrm{O}_{2}$ activated at the interface of $\mathrm{Rh}-\mathrm{TiO}_{2}$, which favored the total $\mathrm{CO}$ conversion at $-50{ }^{\circ} \mathrm{C}$ over this $\mathrm{Rh} / \mathrm{TiO}_{2}$ catalyst reprinted from Ref. [42].

age of $\mathrm{TiO}_{2}$ with weakly adsorbed water greatly changed the number of active sites and facilitated $\mathrm{O}_{2}$ binding and activation. The resulting $\mathrm{Au}-\mathrm{OOH}$ species readily reacted with adsorbed $\mathrm{Au}-\mathrm{CO}$, yielding $\mathrm{Au}-\mathrm{COOH}$ and favoring the production of $\mathrm{CO}_{2}$.

The effect of $\mathrm{OH}$ species is more dominant and important in promotion of $\mathrm{CO}$ oxidation over PGM catalysts at low temperatures than in the case of Au catalysts [46]. Smit et al. [47] reported the crucial role of surface $\mathrm{OH}$ groups on iron oxides, with which $\mathrm{CO}$ reacted to form highly active adsorbed formates, $\mathrm{HCOO}_{(\mathrm{ad}) .}$ Golunski et al. [48] found that the activity of iron oxide-supported Pd catalysts in CO oxidation was significantly enhanced by short exposure to $\mathrm{H}_{2}$, without any subsequent thermal treatment. This was mainly related to the large amount of $\mathrm{OH}$ derived from the $\mathrm{H}_{2}$ treatment. Tomita et al. [49] treated alumina-supported $\mathrm{Pt} / \mathrm{Fe}$ catalysts with water and found that these catalysts could catalyze $\mathrm{CO}$ oxidation at temperatures below $0{ }^{\circ} \mathrm{C}$, with a low apparent activation energy $(9.2 \mathrm{~kJ} / \mathrm{mol})$. The $\mathrm{OH}$ species even played an important role in inert $\mathrm{SiO}_{2}$ supported Pt catalysts. Fukuoka et al. [50] synthesized a catalyst consisting of $\mathrm{Pt}$ nanoparticles in mesoporous silica, and achieved complete $\mathrm{CO}$ conversion at $40{ }^{\circ} \mathrm{C}$. The surface $\mathrm{OH}$ groups on $\mathrm{SiO}_{2}$ attacked the adsorbed $\mathrm{CO}$ on $\mathrm{Pt}$ to form $\mathrm{CO}_{2}$. The presence of $\mathrm{H}_{2}$ significantly enhanced low-temperature $\mathrm{CO}$ oxidation involving the formation of $\mathrm{OH}$ species. This effect was more pronounced when a reducible oxide or an alkali promoter was present. Xu el al. [51] directly proved that the interfacial $\mathrm{CO}_{\text {ads }}+\mathrm{OH}_{\text {ads }}$ reaction on a $\mathrm{FeO}(111) / \mathrm{Pt}(111)$ inverse model catalyst was facile and produced $\mathrm{CO}_{2}$ at the Pt-oxide interface at low temperatures; this provides deep insights into the reaction mechanism. Zhang et al. [26,27] found that the use of $\mathrm{Fe}(\mathrm{OH})_{x}$ promoted the formation of $\mathrm{OH}$ species during $\mathrm{CO}$ oxidation and PROX over Ir/Fe(OH) $)_{x}$ and $\mathrm{Rh} / \mathrm{Fe}(\mathrm{OH})_{x}$ catalysts; this greatly lowered the temperature for $100 \%$ CO conversion to room temperature and improved the catalyst stability. Fig. 5 shows that these $\mathrm{OH}$ species could originate from the reaction between adsorbed $\mathrm{O}$ on $\mathrm{Fe}^{2+}$ sites and adsorbed $\mathrm{H}$ on $\mathrm{Ir}$ or $\mathrm{Rh}$ sites, or activated $\mathrm{H}_{2} \mathrm{O}$ species. They can change the reaction route for $\mathrm{CO}$ oxidation so that it occurs through adsorbed $\mathrm{CO}$ and $\mathrm{OH}$, with a lower activation energy, rather than through adsorbed CO and O. Flytzani-Stephanopoulos et al. [52] suggested that various alkali metals promoted Pt catalysts by stabilizing atomic Pt species in the form $\mathrm{Pt}-\mathrm{O}(\mathrm{OH})_{x}$. The $\mathrm{OH}$ species neighboring the $\mathrm{Pt}$ atoms easily react with $\mathrm{CO}$ to produce $\mathrm{CO}_{2}$.

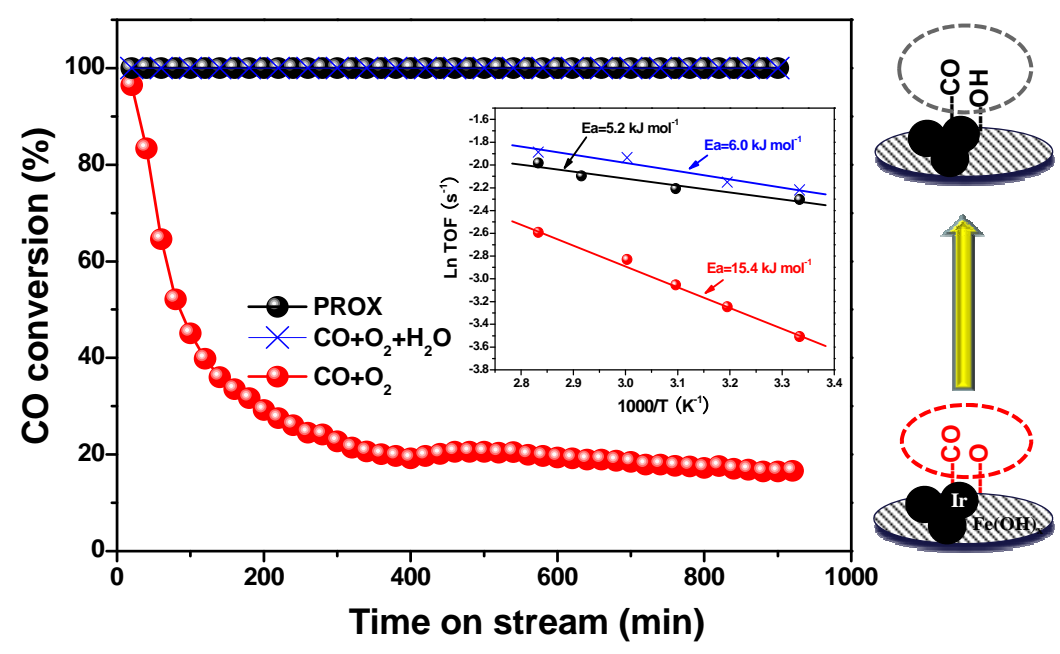

Fig. 5. $\mathrm{CO}$ conversion as a function of reaction time at $40{ }^{\circ} \mathrm{C}$ over $\mathrm{Ir} / \mathrm{Fe}(\mathrm{OH})_{\mathrm{x}}$ catalyst for $\mathrm{CO}$ oxidation with or without the presence of $\mathrm{H}_{2}$ or $\mathrm{H}_{2} \mathrm{O}$; the Inset shows the corresponding Arrhenius plot of Ln TOF vs. 1/T for CO oxidation reprinted from Ref. [26]. 
Recently, Chen et al. [53] have made great progress in the development of Pt-based catalysts for room-temperature oxidation of $\mathrm{CO}$ via $\mathrm{OH}$ species on the catalyst surface. They synthesized iron-nickel hydroxide-platinum (transition metal-OH-Pt) nanoparticles of size less than $5 \mathrm{~nm}$, which can fully remove CO from humid air without activity decay for 1 month. The composition and structure of the $\mathrm{Fe}-\mathrm{OH}-\mathrm{Pt}$ interface showed that the Ni played a key role in stabilizing this interface against dehydration. The $\mathrm{OH}$ groups at the $\mathrm{Fe}^{3+}-\mathrm{OH}-\mathrm{Pt}$ interface readily reacted with the nearby adsorbed $\mathrm{CO}$ to directly yield $\mathrm{CO}_{2}$ and simultaneously form coordinatively unsaturated $\mathrm{Fe}$ sites for $\mathrm{O}_{2}$ activation. The creation of sub-monolayer hydroxides on noble metal clusters is expected to provide an effective method for preparing efficient PGM catalysts for CO oxidation.

\section{Fundamental factors in low-temperature CO oxidation}

\subsection{Effect of metal species size}

The development of characterization techniques for use in heterogeneous catalysis has enabled improved catalyst preparation and design to achieve better catalytic performances. A typical example is the discovery of Au catalysts for CO oxidation. Bulk Au is chemically inert and generally regarded as a poor catalyst. However, highly dispersed nanoscale Au is active in low-temperature $\mathrm{CO}$ oxidation. Haruta et al. [54] found that the turnover frequency in $\mathrm{CO}$ oxidation at $0{ }^{\circ} \mathrm{C}$ increased by one order of magnitude with decreasing Au size from 4 to $2 \mathrm{~nm}$, as shown in Fig. 6. This discovery has caused much excitement in nanocatalysis. In particular, the great advances in high-resolution transmission electron microscopy have enabled the critical role played by the particle size to be observed experimentally. Herzing et al. [55] used aberration-corrected scanning transmission electron microscopy to identify bilayer $\mathrm{Au}$ clusters of size $\sim 0.5 \mathrm{~nm}$ as the active centers for CO oxidation over an $\mathrm{Au} / \mathrm{Fe}_{2} \mathrm{O}_{3}$ catalyst. Qiao et al. [56] prepared an $\mathrm{Au}_{1} / \mathrm{Co}_{3} \mathrm{O}_{4}$ single-atom catalyst with an Au loading of only 0.05 $\mathrm{wt} \%$, which gave almost $100 \%$ CO conversion at room temper-

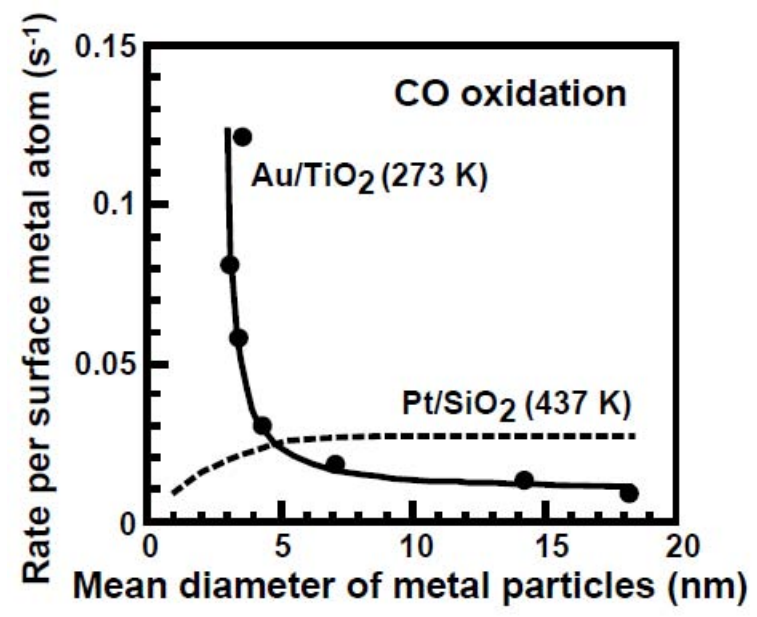

Fig. 6. Turnover frequency of $\mathrm{CO}$ oxidation over $\mathrm{Au}$ and Pt catalysts as a function of particle size above $1 \mathrm{~nm}$ reprinted from Ref. [54]. ature. They found that the $\mathrm{Au}_{1} / \mathrm{CeO}_{2}$ single-atom catalyst was highly active, selective, and extremely stable in preferential CO oxidation in a $\mathrm{H}_{2}$-rich stream, giving $>99.5 \% \mathrm{CO}$ conversion over a wide temperature window, $50-100{ }^{\circ} \mathrm{C}$. This suggests that $\mathrm{Au}$ single-atom catalysts have potential applications [57].

Based on the significant effect of the Au particle size, the effect of changing the PGM particle size on the catalytic activity in CO oxidation was investigated. Initially, it was believed that the Pt particle size had little effect on the CO oxidation activity [54]. Fig. 6 shows that the turnover frequency decreased or remained constant for PGMs with particle sizes lower than $5 \mathrm{~nm}$. However, one crucial point ignored in those studies was that the particles investigated were mostly larger than $2 \mathrm{~nm}$. PGMs with sub-nanoclusters or single atoms were not considered in CO oxidation. A comparison of PGMs and Au shows that CO adsorption is much stronger on PGMs, and this is a crucial cause of their lower activities. Electronic structures and properties can be greatly modified by reducing the particle size to sub-nanometer $(\sim 1 \mathrm{~nm})$ [58-61]. For Pd metal, when the particle size decreased from nano- to sub-nano-clusters, CO adsorption was much weakened because the fraction of linear $\mathrm{CO}$ adsorption, which is more weakly bonded than bridged and multi-bonded species, increased with decreasing particle size $[29,62,63]$. This favors CO desorption and prevents CO poisoning of $\mathrm{Pd}$ in low-temperature oxidation of $\mathrm{CO}$. However, for Pt, Ir, and Rh, it was found that the metal species on sub-nano catalysts were more positively charged than those on nanosized ones [25-28]. CO adsorption microcalorimetry and Fourier-transform infrared spectroscopy provided direct and quantitative evidence of the decreased strength of $\mathrm{CO}$ adsorption from nano to sub-nano species; this can increase the activity in CO oxidation by two orders of magnitude. This is a versatile strategy for PGM catalyst design, enabling total conversion of $\mathrm{CO}$ to $\mathrm{CO}_{2}$ at room temperature. On further decreasing the size to single atoms, the PGM can be stabilized in the form of positive, high-valent atoms with the oxide support connected through oxygen bridges. This helps to reduce the $\mathrm{CO}$ adsorption energy and the activation barriers to CO oxidation. PGM single-atom catalysts on active or inert oxide supports are therefore expected to give good performances in CO oxidation $[30,64,65]$.

\subsection{Importance of interface}

In modern catalyst design strategies, consideration of the indispensable role of the support is important for achieving higher performance [66-68]. The properties of heterogeneous catalysts are often determined by the synergy between the support and metal species, and the active sites are located at the metal-support interface. Bao et al. [23] used a specific preparation method to ensure that the Pt metal species on $\mathrm{Pt} / \mathrm{SiO}_{2}$ and $\mathrm{PtFe} / \mathrm{SiO}_{2}$ were all of size around $2 \mathrm{~nm}$. The $\mathrm{Fe}$ species were present mainly on the outer layers of the Pt-Fe nanoparticles as small patches for the construction of a FeO-on-Pt inverse catalyst. The preferential adsorption and activation of $\mathrm{O}_{2}$ over these coordinatively unsaturated ferrous sites on the interface prevented poisoning by $\mathrm{CO}$, and the 
strength of $\mathrm{CO}$ adsorption on the Pt metal was much decreased. A catalyst consisting of $\mathrm{FeO}$ on an ultrathin $\mathrm{Pt}$ layer with $\mathrm{Cu}$ as an alternative core can impose the same constraint; the Pt interface is decorated with $\mathrm{FeO}$ patches but much less $\mathrm{Pt}$ is used [69]. This type of catalyst gave total CO conversion at room temperature, similar to the case of Pt nanoparticles covered with surface $\mathrm{FeO}$ patches, indicating that the oxide-Pt interface plays a crucial role in CO oxidation. These "oxide-on-metal" catalysts provide a new architecture with enhanced catalytic performance.

The length of the metal-support interface can be tailored exactly by ensuring that the metal species size is monodispersed. Cargnello et al. [70] prepared monodisperse Pd and Pt nanoparticles by thermally decomposing metal (II) acetylacetonates; quantitative control of the metal size can be achieved by varying the surfactant concentration and reaction temperature. Metal-support interfaces of various sizes were obtained by depositing these particles on an active $\mathrm{CeO}_{2}$ support, as shown in Fig. 7. The $\mathrm{CeO}_{2}$-based metal catalysts showed strongly size-dependent activity. The CO oxidation rate decreased with increasing nanoparticle size in all cases. Model analysis results showed that the metal atoms at the nexus of the metal, support, and atmosphere were the active sites for CO oxidation, and smaller particles led to an increased boundary length and higher activity. Size-selected nanoparticles can be used to identify the role of interfacial sites in CO oxidation. Control of the contact dimension of the metal-support interface is another crucial factor in improving the length of interface sites. A study of the role of the Pt-Fe interface in maximizing the quantity of $\mathrm{OH}$ species provided direct evidence of this aspect, i.e., that the active species is an $\mathrm{Fe}^{3+}-\mathrm{OH}-\mathrm{Pt}$ ensemble [53]. As shown in Fig. 8, to maximize the Pt-Fe interface, an alloy-assisted strategy was developed instead of a core-shell one which was not an ideal solution because most Pt atoms

(a)
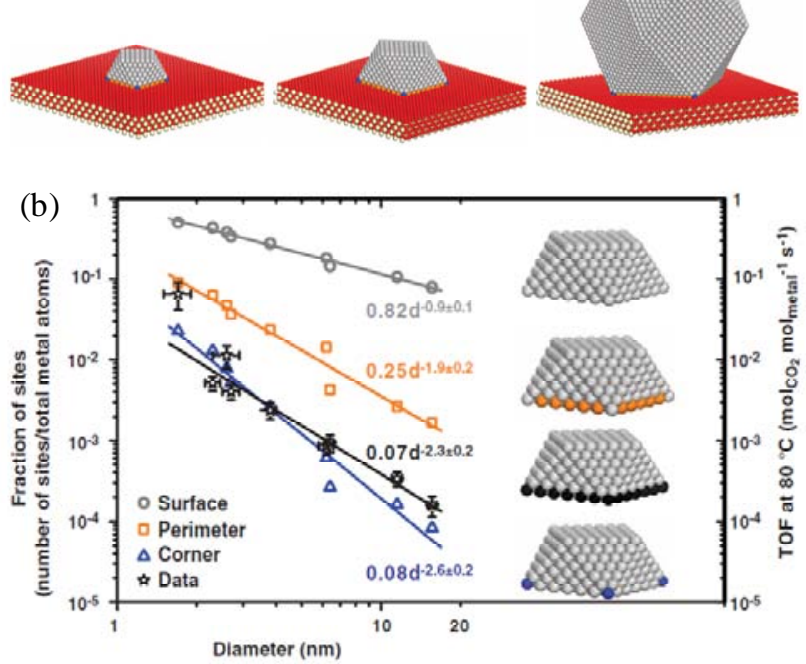

Fig. 7. (a) Schematic illustration of the length of metal-support interface by controlling the size of metal species; (b) A model analysis of number of sites and TOF for $\mathrm{CO}$ oxidation at $80{ }^{\circ} \mathrm{C}$ with a particular geometry (surface and perimeter or corner atoms in contact with the support) reprinted from Ref. [70].

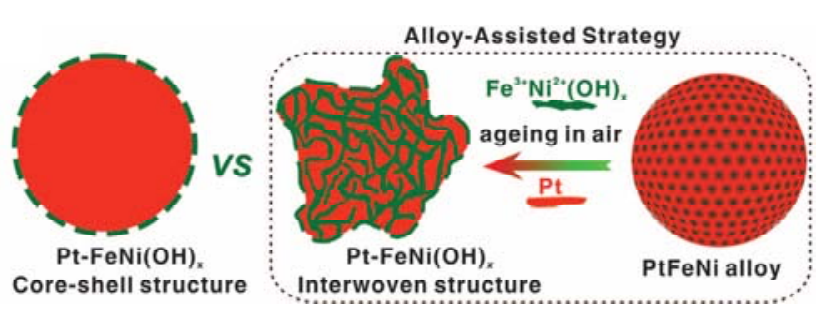

Fig. 8. Schematic illustration of the length of metal-support interface by changing contact dimension between metal and support reprinted from Ref. [53].

were not located on the surface. High-temperature-air-aged PtFeNi nanoparticles formed particles with interwoven, highly irregular structures on their surfaces. The number of Pt-OH-M sites on the PtFeNi catalysts can be increased by high Pt dispersion, and coordination of a high number of $\mathrm{O}$ species with Pt. If the Pt-Fe contact length is greater, a higher amount of $\mathrm{OH}$ species remain at the interface. Catalysts with such structures are highly stable, both in the reaction stream and during prolonged storage. The metal-support interactions can be changed by varying the metal size or the contact dimension; this enables clear and fundamental recognition of the interface sites between the metal and support in the low-temperature oxidation of CO.

\section{Summary and remarks}

The pioneering work by Haruta et al. which showed that CO could be oxidized over Au catalysts at low temperatures, initiated the research hot topic of nanocatalysis, and led to in-depth investigation of whether this goal can be achieved by tailoring PGM-based catalysts to have properties similar to those of $\mathrm{Au}$ catalysts. In this mini-review, we summarized recent advances in high-performance PGM catalysts for CO oxidation at or below room temperature. Weakening $\mathrm{CO}$ adsorption or providing alternative sites for $\mathrm{O}_{2}$ adsorption/activation (or both) provides the basic strategy for enhancing the low-temperature activities of PGMs. Some excellent contributions have been made and fundamental recognition of active sites or species for designing highly effective catalysts has been achieved.

The fast development of nanotechnology has enabled the development of strategies for accurately controlling catalyst structures by decreasing the metal species size from nano to sub-nano, or even to single atoms, and engineering metal-metal oxide (hydroxide) interfaces. The PGM particle size can be changed in parallel with a change in the valence state from zero-valent to positive. In particular, maximum dispersion of PGMs in the form of single atoms gives positively charged, high-valent states. These factors help to reduce both the CO adsorption strength and activation barriers to $\mathrm{CO}$ oxidation. The metal-support interfaces can be engineered to favor CO oxidation with direct participation at the perimeter. Maximizing the length of the metal-support interface enables the active metal species or $\mathrm{OH}$ species to be tailored, which can change the $\mathrm{CO}$ oxidation route from a reaction of $\mathrm{CO}$ with oxygen species to one with $\mathrm{OH}$ species. 
Advances in characterization techniques have enabled new catalysts or reaction routes for $\mathrm{CO}$ oxidation at or even far below room temperature to be identified. Adsorbed CO is supplied not only from metal sites but also from the support. CO adsorption on $\mathrm{TiO}_{2}$ support is much weaker than that on $\mathrm{Rh}$ sites, which acts as active species; this enables $\mathrm{Rh} / \mathrm{TiO}_{2}$ to catalyze CO oxidation at low temperatures. Furthermore, it is clear that $\mathrm{O}_{2}$ activation is generally a key step in $\mathrm{CO}$ oxidation; however, $\mathrm{O}_{2}$ is easily dissociated to atomic oxygen species on PGMs, and these can only react with $\mathrm{CO}$ above room temperature. Charge transfer from the support, probably from the metal-support interface sites, to the adsorbed $\mathrm{O}_{2}$ species favors the formation of negatively charged molecular $\mathrm{O}_{2}$ species such as superoxides or peroxides. These oxygen species are active and favor CO oxidation even at cryogenic temperatures. We therefore believe that a wide range of PGM catalysts with excellent performances, even comparable to those of Au catalysts, in CO oxidation at room temperature and cryogenic temperatures, will be developed.

\section{References}

[1] H. J. Freund, G. Meijer, M. Scheffler, R. Schlögl, M. Wolf, Angew. Chem. Int. Ed., 2011, 50, 10064-10094.

[2] M. V. Twigg, Appl. Catal. B, 2007, 70, 2-15.

[3] K. Liu, A. Q. Wang, T. Zhang, ACS Catal., 2012, 2, 1165-1178.

[4] A. B. Lamb, W. C. Bray, J. C. W. Frazer, J. Ind. Eng. Chem., 1920, 12, 213-221.

[5] D. R. Merrill, C. C. Scalione, J. Am. Chem. Soc., 1921, 43, 1982-2002.

[6] C. Yoon, D. L. Cocke, J. Catal., 1988, 113, 267-280.

[7] X. W. Xie, Y. Li, Z. Q. Liu, M. Haruta, W. J. Shen, Nature, 2009, 458, 746-749.

[8] M. Haruta, T. Kobayashi, H. Sano, N. Yamada, Chem. Lett., 1987, 405-408.

[9] M. Haruta, N. Yamada, T. Kobayahsi, S. Iijima, J. Catal., 1989, 115, 301-309.

[10] M. Haruta, Nature, 2005, 437, 1098-1099.

[11] S. Golunski, Platinum Met. Rev., 2013, 57, 82-84.
[12] I. Langmuir, Trans. Faraday Soc., 1922, 17, 621-654.

[13] D. Widmann, R. J. Behm, Acc. Chem. Res., 2014, 47, 740-749.

[14] A. D. Allian, K. Takanabe, K. L. Fujdala, X. H. Hao, T. J. Truex, J. Cai, C. Buda, M. Neurock, E. Iglesia, J. Am. Chem. Soc., 2011, 133, 4498-4517.

[15] W. D. Michalak, J. M. Krier, S. Alayoglu, J. Y. Shin, K. An, K. Komvopoulos, Z. Liu, G. A. Somorjai, J. Catal., 2014, 312, 17-25.

[16] B. T. Qiao, L. Q. Liu, J. Zhang, Y. Q. Deng, J. Catal., 2009, 261, 241-244.

[17] L. Q. Liu, F. Zhou, L. G. Wang, X. J. Qi, F. Shi, Y. Q. Deng, J. Catal., 2010, 274, 1-10.

[18] L. Q. Liu, B. T. Qiao, Y. D. He, F. Zhou, B. Q. Yang, Y. Q. Deng, J. Catal,, 2012, 294, 29-36.

[19] X.L. Tang, B.C. Zhang, Y. Li, Q. Xin, W.J. Shen, Chin. J. Catal., 2005, $26,1-3$.

[20] W. S. Zhang, A. Q. Wang, L. Li, X. D. Wang, T. Zhang, Catal. Today, 2008, 131, 457-463.

[21] K. Liu, A. Q. Wang, W. S. Zhang, J. H. Wang, Y. Q. Huang, J. Y. Shen, T. Zhang, J. Phys. Chem. C, 2008, 114, 8533-8541.

[22] Y. N. Sun, Z. H. Qin, M. Lewandowski, E. Carrasco, M. Sterrer, S. Shaikhutdinov, H. J. Freund, J. Catal, 2009, 266, 359-368.

[23] Q. Fu, W. X. Li, Y. X. Yao, H. Y. Liu, H. Y. Su, D. Ma, X. K. Gu, L. M. Chen, Z. Wang, H. Zhang, B. Wang, X. H. Bao, Science, 2010, 328, 1141-1144.

[24] P. Li, D. E. Miser, S. Rabiei, R. T. Yadav, M. R. Hajaligol, Appl. Catal. $B, 2003,43,151-162$.

[25] J. Lin, B. T. Qiao, J. Y. Liu, Y. Q. Huang, A. Q. Wang, L. Li, W. S. Zhang, L. F. Allard, X. D. Wang, T. Zhang, Angew. Chem. Int. Ed., 2012, 51, 2920-2924.

[26] J. Lin, B. T. Qiao, L. Li, H. L. Guan, C. Y. Ruan, A. Q. Wang, W. S. Zhang, X. D. Wang, T. Zhang, J.Catal., 2014, 319,142-149.

[27] H. L. Guan, J. Lin, L. Li, X. D. Wang, T. Zhang, Appl. Catal. B, 2016, 184, 299-308.

[28] B. T. Qiao, A. Q. Wang, L. Li, Q. Q. Lin, H. S. Wei, J. Y. Liu, T. Zhang, ACS Catal., 2014, 4, 2113-2117.

[29] B. T. Qiao, J. Lin, L. Li, A. Q. Wang, J. Y. Liu, T. Zhang, ChemCatChem, 2014, 6, 547-554.

[30] B. T. Qiao, A. Q. Wang, X. F. Yang, L. F. Allard, Z. Jiang, Y. T. Cui, J. Y. Liu, J. Li, T. Zhang, Nat. Chem.,2011, 3, 634-641.

[31] J. Lin, A. Q. Wang, B. T. Qiao, X. Y. Liu, X. F. Yang, X. D. Wang, J. X.

\section{Graphical Abstract}

Chin. J. Catal., 2016, 37: 1805-1813 doi: 10.1016/S1872-2067(16)62513-5

\section{Recent progress in CO oxidation over Pt-group-metal catalysts at low temperatures}

Jian Lin, Xiaodong Wang *, Tao Zhang*

Dalian Institute of Chemical Physics, Chinese Academy of Sciences

This mini-review summarized the advances of various PGM ( $\mathrm{Pt}, \mathrm{Pd}, \mathrm{Ir}, \mathrm{Rh}, \mathrm{Ru}$ ) catalysts for $\mathrm{CO}$ oxidation at low temperatures in the past decade, especially those exhibiting comparable performance with the standard gold catalyst.

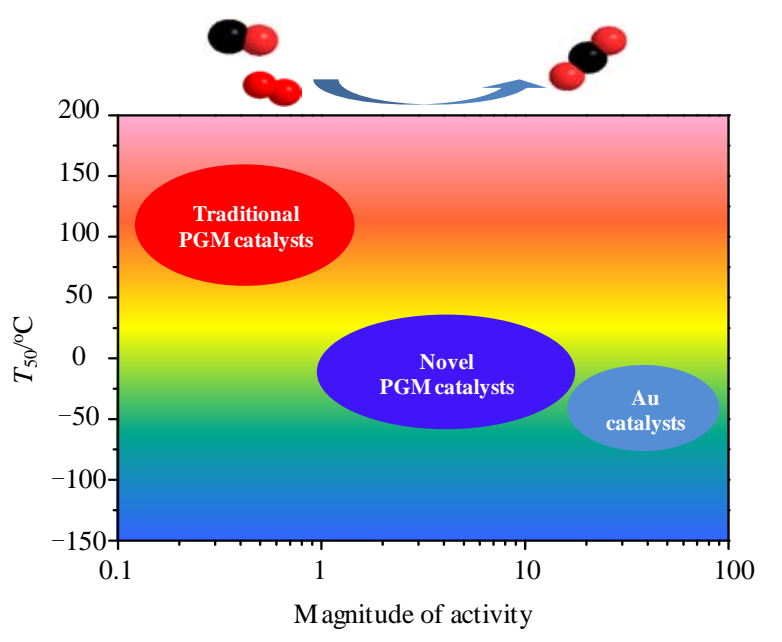


Liang, J. Li, J. Y. Liu, T. Zhang, J. Am. Chem. Soc., 2013, 135, 15314-15317.

[32] J. Lin, B. T. Qiao, N. Li, L. Li, X. C. Sun, J. Y. Liu, X. D. Wang, T. Zhang, Chem. Commun., 2015, 51, 7911-7914.

[33] X. F. Yang, A. Q. Wang, B. T. Qiao, J. Li, J. Y. Liu, T. Zhang, Acc. Chem. Res., 2013, 46, 1740-1748.

[34] H. Q. Zhu, Z. F. Qin, W. J. Shan, W. J. Shen, J. G. Wang, J. Catal., 2005, 233, 41-50.

[35] E. Y. Ko, E. D. Park, H. C. Lee, D. Lee, S. Kim, Angew. Chem. Int. Ed., 2007, 46, 734-737.

[36] S. Alayoglu, A. U. Nilekar, M. Mavrikakis, B. Eichhorn, Nat. Mater., 2008, 7, 333-338.

[37] D. Widmann, R.J. Behm, Angew. Chem. Int. Ed., 2011, 50, 10241-10245.

[38] M. Okumura, N. Masuyama, E. Konishi, S. Ichikawa, T. Akita, J. Catal., 2002, 208, 485-489.

[39] F. Yang, S. Kundu, A. B. Vidal, J. Graciani, P. J. Ramírez, S. D. Senanayake, D. Stacchiola, J. Evans, P. F. Liu, J. Sanz, J. A. Rodriguez, Angew. Chem. Int. Ed., 2011, 50, 10198-10202.

[40] I. X. Green, W. J. Tang, M. Neurock, J. T. Yates, Science, 2011, 333, 736-739.

[41] I. Lee, F. Zaera, J. Catal., 2014, 319, 155-162.

[42] H. L. Guan, J. Lin, B. T. Qiao, X. F. Yang, L. Li, S. Miao, J. Y. Liu, A. Q. Wang, X. D. Wang, T. Zhang, Angew. Chem. Int. Ed., 2016, 55, 2820-2824.

[43] K. Liu, A. Q. Wang, W. S. Zhang, J. H. Wang, Y. Q. Huang, X. F. Wang, J. Y. Shen, T. Zhang, Ind. Eng. Chem. Res., 2010, 50, 758-766.

[44] M. Daté, M. Okumura, S. Tsubota, M. Haruta, Angew. Chem. Int. Ed., 2004, 43, 2129-2132.

[45] J. Saavedra, H. A. Doan, C. J. Pursell, L. C. Grabow, B. D. Chandler, Science, 2014, 345, 1599-1602.

[46] H. F. Wang, R. Kavanagh, Y. L. Guo, Y. Guo, G. Z. Lu, P. Hu, Angew. Chem. Int. Ed., 2012, 51, 6657-6661.

[47] G. Šmit, S. Zrncevic, K. Lázár, J. Mol. Catal. A, 2006, 252, 103-106.

[48] S. Golunski, R. Rajaram, N. Hodge, G. J. Hutchings, C. J. Kiely, Catal. Today, 2002, 72, 107-113.

[49] A. Tomita, K. Shimizu, K. Kato, Y. Tai, Catal. Commun., 2012, 17, 194-199.

[50] A. Fukuoka, J. Kimura, T. Oshio, Y. Sakamoto, M. Ichikawa, J. Am. Chem. Soc., 2007, 29, 10120-10125.

[51] L. S. Xu, Y. S. Ma, Y. L. Zhang, Z. Q. Jiang, W. X. Huang, J. Am. Chem. Soc., 2009, 131, 16366-16367.
[52] M. Yang, S. Li, Y. Wang, J. A. Herron, Y. Xu, L. F. Allard, S. Lee, J. Huang, M. Mavrikakis, M. Flytzani-Stephanopoulos, Science, 2014, 346, 1498-1501.

[53] G. X. Chen, Y. Zhao, G. Fu, P. N. Duchesne, L. Gu, Y. P. Zheng, X. F. Weng, M. S. Chen, P. Zhang, C. W. Pao, J. F. Lee, N. F. Zheng, Science, 2014, 344, 495-499.

[54] M. Haruta, Chem. Rec., 2003, 3, 75-87.

[55] A. A. Herzing, C. J. Kiely, A. F. Carley, P. Landon, G. J. Hutchings, Science, 2008, 321, 1331-1334.

[56] B. T. Qiao, J. Lin, A. Q. Wang, Y. Chen, T. Zhang, J. Y. Liu, Chin. J. Catal., 2015, 36, 1505-1511.

[57] B. T. Qiao, J. X. Liu, Y. G. Wang, Q. Q. Lin, X. Y. Liu, A. Q. Wang, J. Li, T. Zhang, J. Y. Liu, ACS Catal., 2015, 5, 6249-6254.

[58] H. V. Roy, P. Fayet, F. Patthey, W. D. Schneider, B. Delley, C. Massobrio, Phys. Rev. B,1994, 49, 5611-5620.

[59] D. A. J. M. Ligthart, R. A. van Santen, E. J. M. Hensen, Angew. Chem. Int. Ed., 2011, 50, 5306-5310.

[60] S. F. J. Hackett, R. M. Brydson, M. H. Gass, I. Harvey, A. D. Newman, K. Wilson, A. F. Lee, Angew. Chem. Int. Ed.,2007, 46, 8593-8596.

[61] W. E. Kaden, T. Wu, W. A. Kunkel, S. L. Anderson, Science, 2009, 326, 826-829.

[62] A. Guerrero-Ruiz, S. Yang, Q. Xin, A. Maroto-Valiente, M. Benito-Gonzalez, I. Rodriguez-Ramos, Langmuir, 2000, 16, 8100-8106.

[63] J. H. Fischer-Wolfarth, J. A. Farmer, J. M. Flores-Camacho, A. Genest, I. V. Yudanov, N. Rçsch, C. T. Campbell, S. Schauermann, H. J. Freund, Phys. Rev. B, 2010, 81, 241416/1-241416/4.

[64] M. Moses-DeBusk, M. Yoon, L. F. Allard, D. R. Mullins, Z. L. Wu, X. F. Yang, G. Veith, G. M. Stocks, C. K. Narula, J. Am. Chem. Soc., 2013, 135, 12634-12637.

[65] E. J. Peterson, A. T. DeLaRiva, S. Lin, R. S. Johnson, H. Guo, J. T. Miller, J. H. Kwak, C. H. F. Peden, B. Kiefer, L. F. Allard, F. H. Ribeiro, A. K. Datye, Nat. Commun., 2014, 5, 4885.

[66] E. G. Derouane, CATTECH, 2001, 5, 214-225.

[67] P. Sonström, D. Arndt, X. Wang, V. Zielasek, M. Bäumer, Angew. Chem. Int. Ed., 2011, 50, 3888-3891.

[68] G. M. Veith, A. R. Lupini, S. J. Pennycook, N. J. Dudney, ChemCatChem, 2010, 2, 281-286.

[69] X. G. Guo, Q. Fu, Y. X. Ning, M. M. Wei, M. R. Li, S. Zhang, Z. Jiang, X. H. Bao, J. Am. Chem. Soc., 2012, 134, 12350-12353.

[70] M. Cargnello, V. V. T. Doan-Nguyen, T. R. Gordon, R. E. Diaz, E. A. Stach, R. J. Gorte, P. Fornasiero, C. B. Murray, Science, 2013, 34, 771-774.

\title{
铂族金属催化剂低温 CO 氧化研究近期进展
}

\author{
林 坚, 王晓东, 张 涛* \\ 中国科学院大连化学物理研究所, 催化基础国家重点实验室, 辽宁大连, 116023
}

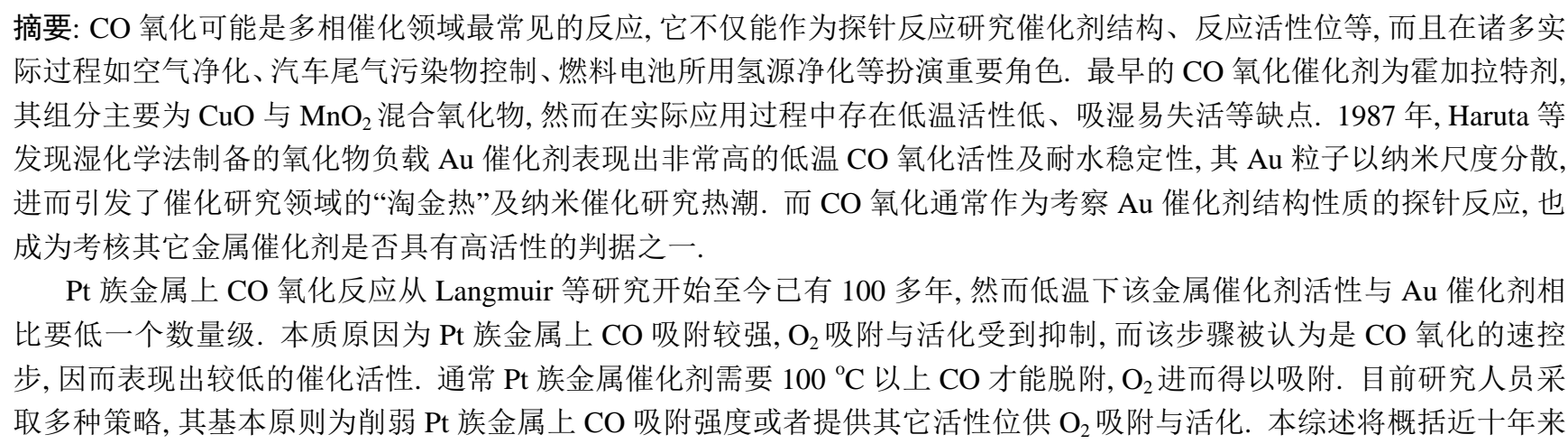


Pt 族金属催化剂 CO 氧化研究进展, 主要总结室温甚至超低温条件下的研究成果.

高活性 $\mathrm{CO}$ 氧化催化剂主要是通过采用可还原氧化物为载体或助剂, 或者改变催化剂表面性质如使表面富 $\mathrm{OH}$ 基物种 来形成. Au 催化剂的研究发现, 改变金属粒子尺寸极有可能获得不同寻常的催化性能, 而常规的 Pt 族金属催化剂研究主 要是在纳米尺度. 近期人们发现逐渐减小 Pt 族金属粒子尺寸, 从纳米到亚纳米甚至单原子时, 其电荷状态逐渐呈正价形 式, 这有利于削弱其 CO 吸附强度. 此外, 可通过增强金属载体间的相互作用, 改变金属载体接触方式, 如从核壳到交叉结 联结构, 构筑出更多的金属载体界面, 使得 $\mathrm{O}_{2}$ 更容易吸附与活化或稳定更多的 $\mathrm{OH}$ 基物种进而在此界面与吸附的 $\mathrm{CO}$ 反 应.

伴随着表征技术的发展, $\mathrm{CO}$ 氧化机理的认识也更加深入, 这给催化剂的设计带来更多新的思路. (1) 改变 CO 吸附活 化位, 将 $\mathrm{CO}$ 吸附活化位从金属转移到载体上, 从而大大降低 $\mathrm{CO}$ 吸附强度, 活化的 $\mathrm{CO}$ 物种在反应过程中容易溢流到金属 载体界面处, 这甚至有利于超低温度下 $\left(-100{ }^{\circ} \mathrm{C}\right.$ 左右) $\mathrm{CO}$ 氧化. (2) 改变 $\mathrm{O}_{2}$ 活化形式. $\mathrm{O}_{2}$ 通常在 $\mathrm{Pt}$ 族金属上容易以解离 氧原子形式存在, 通过改变载体、金属载体界面性质使得 $\mathrm{O}_{2}$ 以分子氧形式活化, 如形成超氧或过氧物种, 这有利于降低 $\mathrm{CO}$ 氧化的活化能垒, 进而提高其低温甚至超低温下 $\mathrm{CO}$ 氧化活性. 今后, 设计并合成出在超低温度下能够氧化 CO 的 Pt 族金 属催化剂将成为 $\mathrm{CO}$ 氧化催化剂研究的重要方向之一.

关键词: 一氧化碳氧化; 金; 铂族金属; 低温; 尺寸效应; 界面

收稿日期: 2016-06-25. 接受日期: 2016-07-30. 出版日期: 2016-11-05.

*通讯联系人. 电话: (0411)84379015; 传真: (0411)84691570; 电子信箱: taozhang@dicp.ac.cn

\#通讯联系人.电话: (0411)84379680; 传真: (0411)84691570; 电子信箱: xdwang@dicp.ac.cn

基金来源：国家自然科学基金 (21076211，21203181，21576251，21676269); 中国科学院 B 类战略性先导科技专项 (XDB17020100); 科技部重大研发计划2016YFA0202801; 辽宁省科技厅院士基金2015020086-101.

本文的英文电子版由Elsevier出版社在ScienceDirect上出版(http://www.sciencedirect.com/science/journal/18722067).

\section{For Author Index:}

\section{LIN Jian, WANG Xiaodong, ZHANG Tao}

